\title{
Studies on Influence of Internet Culture on College Students' Moral Emotions
}

\author{
Xu Shengnan ${ }^{1, \text { a }}$ \\ 1,Southwest Jiao Tong University ,ChengDu, Sichuan 610031, China \\ a421509777@qq.com
}

Keywords: Internet culture; college students; moral emotion

\begin{abstract}
Although internet has brought great convenience for people's life, there are still some negative elements in internet culture, which influence college students' moral emotion construction. This paper puts forward how to use internet culture to build college students' moral emotions, in order to push the value of internet culture forward in a better way and to realize the shaping of college students' moral emotions.
\end{abstract}

\section{Connotation and characteristics of internet culture}

Internet culture is a kind of culture formed and prevailing in internet, which is a production of internet. Internet culture refers to the human culture in the internet times; internet culture, broadly speaking, is a part of human culture, an embodiment of traditional culture and morality; narrowly speaking, internet culture refers to the culture formed in the process of innovative activities on the basis of internet technology and information internet technology[1]. Characteristics of internet culture include: rich information in internet culture; little value in internet culture; flourishing of materialism and hedonism in internet culture.

\section{Division of moral emotion dimensions of college students}

Generalization and superficial feature of moral emotions:The generalization and superficial feature of moral emotions can be regarded as the primary stage of college students; and at this period, college students start to understand moral emotions, and therefore, they don't have deep understanding on the content of moral emotions and thinking ways. Although the college students have very upward, they cannot find corresponding methods and ways, and only suppress patriotism or sense of justice in the heart. Students at this age are positive and active on the whole; with their own limits, the moral emotions are on the surface, which shows generalization and superficial feature[2].

Implicit and fading features of moral emotions:The moral emotions of students at this age tend to be mature, but start to become implicit and fading. With studying at school, their self-awareness becomes mature and start to focus on and protect their own images; they begin to control and adjust their emotions on purpose, from which we get the data in Table 1: among the 60 students under investigation, more than $70 \%$ of students are willing to help the others on the condition of not harming their own interests, and they will not help others if it needs sacrificing their own benefits; $25 \%$ of college students believe that others have nothing to do with themselves, and only $5 \%$ of college students are not willing to help the others regardless of their own interests. From the data, we can see that the moral emotions of a quarter of students have started to fade and show extreme indifference; there are also some college students who are willing to help the others on certain conditions, such as without losing their own profit; college students who are willing to help the others without preconditions are only very few. 
Table 1. On the questionnaire of "whether you are willing to help the others"

\begin{tabular}{|l|c|c|c|}
\hline \hline Choice of answers & Number of people & $\begin{array}{c}\text { Percentage } \\
\text { (\%) }\end{array}$ & Problems \\
\hline $\begin{array}{l}\text { Willing to help the others without } \\
\text { sacrificing their own interests }\end{array}$ & 42 & $70 \%$ & Selfish \\
\hline $\begin{array}{l}\text { Other people have nothing to do } \\
\text { with them; it is not necessary to } \\
\text { help them. }\end{array}$ & 15 & $25 \%$ & Indifferent \\
\hline $\begin{array}{l}\text { Willing to help the others without } \\
\text { any conditions, even on the } \\
\text { condition of sacrificing their own } \\
\text { interests. }\end{array}$ & 3 & $5 \%$ & Great \\
\hline
\end{tabular}

Stability and volatility of moral emotions:After entering the second dimension, the moral emotions of college students have developed to certain extent, which are in a relative mature stage; but at this stage, their moral emotions begin to volatile. This leads to the interactions between moral emotions and behaviors; as the students are not good at controlling their own emotions with moralities, stability and volatility exist at the same time.

Complexity and contradiction of moral emotions: With the influence of internet environment, college students' culture and life start to enrich, and they show the balance between themselves and the other people, the collective, and the society in the aspect of moral emotions. On one hand, college students emphasize the independence of individuals and have great self-confidence. But on the other hand, with many limits in real life, the inner world of college students start to change, and they begin to balance whether their own behaviors are worth it before making choices. When they meet unfairness, instead of striving for the victims, they are concerned about losing their own interests; thus, they are not fearless and hide their real feelings and emotions, and their inner world becomes complex and contradict.

\section{Third dimension, reasonable stage}

Co-existence of implicitness and explicitness:In college study, students' self-awareness continually grows and becomes mature; but some of college students have improper arrangement of life and study after entering college or develop unharmonious relationship with the others, which easily leads to anxiety and confusion; on the other hand, they hide the side of craze and briskness, and their moral emotions show a mixture of implicitness and explicitness.

Co-existence of morality and utilitarianism:When moral emotions develop into a rather mature stage, they are revealed in a natural way. The basic feature of moral emotions is that is always connects with certain needs and interests. When the mentality and thinking become mature, college students can make the right choices, insist on relying on their own efforts, refuse opportunism; stick to fair competition instead of securing advantages through influence, and so on[3]. In general, the moral emotions of college students take morality and justice as the main stream, but on some details, they still cannot avoid the influence brought by internet culture and social experience, causing the co-existence of morality and utilitarianism.

\section{Problems of college students' moral emotions against the background internet culture}

Self-awareness is not exact:Nowadays, college students live in a society with developed internet and all kinds of information is transmitted fast; in a world of internet culture, the relationship between college students and the society and worlds are becoming closer and closer, and they have new knowledge about the society and the world, and their inner activities are richer, freer and bolder. With the influence of internet, many college students start to make unreal 
imagination, which has no help on their work and study, but on the contrary, stops their steps forward.

Short of care for and help the others:In a society that change rapidly, college students are faced with unprecedented challenges of values, and various moral emotions mix together, among which the contract with people occupies important part. However, in real life, with the impact of internet culture, the thoughts of material first, money first, profit first and so on also affect the inner activities of college students; in the aspect of making friends, they start to choose friends according to the such rules as whether they are powerful, have money or can offer help, instead of whether they have something in common on emotional level; the mental state of college students to make friends start to be complex and twisted[4].

Short of responsibility sense for the society and nation:In social life, sense of responsibility and mission are the basic moral emotion of college students as a part of the society; according to investigation, the sense of responsibility and mission among students at primary schools is as high as $90 \%$; the sense of responsibility and mission among students at high schools is only $70 \%$; the sense of responsibility and mission among students at colleges is only 40\%[5]. This set of data fully shows that from primary school to high school, to college, the sense of responsibility and mission is gradually going down, and in front of the choice of interests of nation, society and individual, some college students only emphasize individual interests, instead of fully considering their responsibility for the society and sense of mission for the nation.

\section{How to deal with the influence of internet culture on the moral emotions of college students}

Strengthen internet supervision and enhance college students' ability to distinguish:As the internet culture is open, college students is relatively free to publish information and to communicate. However, as the internet supervision in our country is lagged behind, some lawless persons utilize our supervision loopholes and adopt improper means to perform criminal acts. Thus, to provide guidance and supervision on internet culture is a necessary requirement in the ideological and political education of college students[6]. Internet culture is spread in a dynamic, novel and complicated way, changing values of college students imperceptibly.

Guide students' internet activities directly:Internet is a double-edged sword; although there are much unfavorable content in internet culture which is mentioned above, we still can make use of it, such as advising students to focus on some experts or predecessors in some professional fields, encouraging students or masters or predecessors to communicate, and recommending students some valuable websites or movies, to guide their internet activities[7].

Hole colorful practical activities to reinforce the contact between students and the society:The formation of moral emotions cannot be cut from social practice; to gain the experience of moral emotions, college students should participate in activities of moral practice actively. According to the data from investigation, $54 \%$ of college students believe that the way to gain moral emotions is to participate in social activities; $16 \%$ of college students believe that moral emotions are gained in class activities; $9 \%$ of college students think that moral emotions are gained in class activities. Therefore, in the education, we should distract college students' attention from various perspectives[8]. Internet cannot solve all of the problems.

Thus, colleges should hold colorful activities, such as seminars, lectures, social research, PE activities, and social service, and so on, to encourage students to take part in and to satisfy their enthusiasm and pursuit for life. Through firsthand experience, college students can get knowledge that cannot be found in internet or books, learn how to blend in this society, and elevate the level of their moral emotions.

\section{References}

[1]Wan Feng. Analysis on connotation and characteristics of internet culture [J]. Education Research Monthly, 2010 (4)

[2]Jiao Jiao. Cultivation and construction of moral emotions of college students [D]. Liaoning 
Normal University, thesis of master's degree, 2013

[3] Xu Liyan, Guan Xianping. College moral education: Domination of college students' moral choosing competence [J]. High education forum, 2010(12)

[4] Gai Fangpeng. Study on negative influence of internet on college students and education strategies [D]. Shandong University 2011

[5] Wang Ping. Study on influence of internet culture on college students and strategies [D].South Central University for Nationalities, thesis of master's degree, 2012

[6] Ju Xiaotian. Shock of internet culture on college students' value and adjustments [D]. Dalian Maritime Univeristy, thesis of master's degree, 2013

[7]Oriel FeldmanHall,Dean Mobbs,Davy Evans,Lucy Hiscox,Lauren Navrady,Tim Dalgleish. What we say and what we do: The relationship between real and hypothetical moral choices[J]. Cognition . 2012 (3)

[8]Russell,B.Skeptical essays, eastern and western ideals of happiness. RoutledgeClassics . 2004 